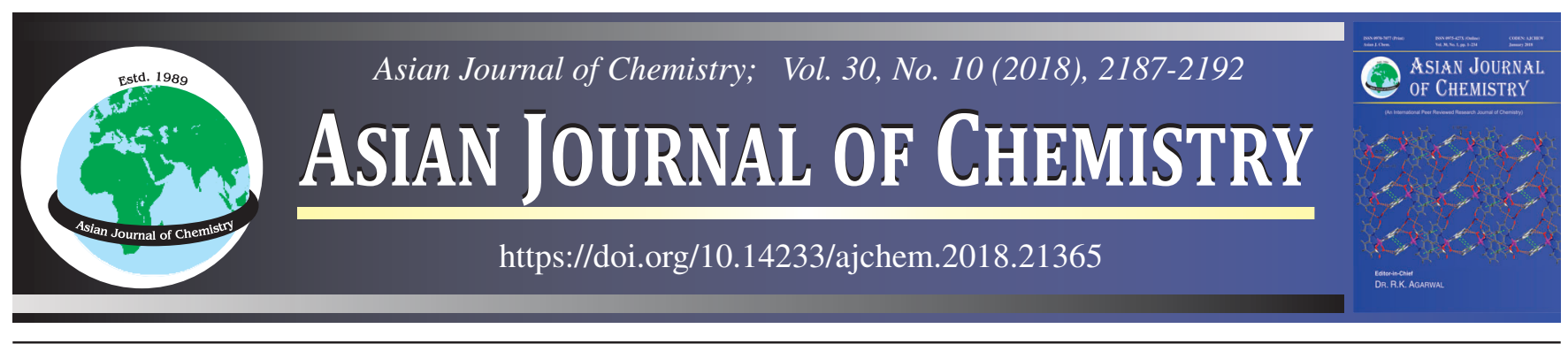

\title{
New Derivative Benzothiazole Suspend Diphenyleamine Based Aromatic Polyamides as Electrochromic Light Emitting Devices
}

\begin{abstract}
AZHAR KAMIL RASHID
Department of Chemistry, College of Education for Pure Science/Ibn Al-Haitham, University of Baghdad, Baghdad, Iraq

Corresponding author: Tel: +964 7714794280; E-mail: azhar_almasody@yahoo.co.uk

Received: 4 April 2018;

Accepted: 26 June 2018;

Published online: 31 August 2018;

AJC-19041

In this work, a set of some substituted aromatic polyamides containing (benzothiazole)diphenylamine moieties (P1-P5) was prepared via the phosphorylation polycondensation technique from the reaction of several aromatic dicarboxylic acids with synthesized N,N-bis $(4-$ aminophenyl)2-amine-6-methoxybenzothiazol (M). It was prepared from the cesium fluoride-mediated double $\mathrm{N}$-arylation reaction of 6methoxybenzothiazol (a) with $p$-fluoronitrobenzene to form dinitro intermediate (I) followed by palladium-catalyzed hydrazine reduction FTIR, ${ }^{1} \mathrm{H}$ and ${ }^{13} \mathrm{C}$ NMR spectra techniques were utilized to characterize the chemical structures of all the resultant intermediates and polyamides. Thermal analysis revealed that the synthesized polyamides showed perfect thermal stability and superior glass transition temperatures $\left(\mathrm{T}_{\mathrm{g}}\right)$. Dilute solutions of these polyamides in $\mathrm{N}$-methyl pyrrolidone $\left(10^{-5} \mathrm{M}\right)$ showed good optical properties where exhibited intensive photoluminescence in the region of blue colour. Cyclic voltammograms of the synthesized polymers membrane molding onto the basis of ITO-plated glass in the spesial electrolyte contains $10^{-1} \mathrm{M}$ of tetrabutylammonium perchlorate $(\mathrm{TBAP})$ in dry $\mathrm{CH}_{3} \mathrm{CN}$ which exhibited one oxidation redox wave couples.

Keywords: Polyamides, Photoreceptor, Electrochromic, Photoluminescence.

ᄂ - - - - - - - - - - - - - - - - - - - - - - - - - - - - - -
\end{abstract}

\section{INTRODUCTION}

Most of the aromatic polyamides are a type of high active polymers because of their perfect mechanical behaviour, high chemical resistance and high thermal stability [1-3]. Many attempts have been done to enhance the solubility and process ability of these polymers through constitutional improvement of their monomers [4-6].

In modern studies, polyamides materials have been quite used in organic electronic-devices like light-emitting diodes, transistors [7,8]. Aromatic amines always used in structure of hole-emitting polymers in the electronic diodes as electroacceptor diodes [9] and organic light emitting devices (OLEDs) $[10,11]$. All electro-acceptor polyamides gave reversible visible changes in absorption or transmittance upon electrochemically oxidized or reduced like conjugated polymers, inorganic coordination and transition-metal oxides complexes $[12,13]$.

Triphenylamine (TPA) and diphenylamine (DPA) are recognized for their electro and photoactive behaviours lead to operate as photo electronic applications in electro- photography, electro-luminescent devices, electronic transistors, photo cells and electrochromic or electrofluorochromicdiodes [14-18].

Triphynelamines are known readily oxidized to product stable radical cations provided that the para-position of the phenyl group with the oxidation process are still kept and are always done with a strong different in colours. During the late years, a large number of excellent-application of aromatic polyamides and its polyimides with strong and active redox groups (DPA and TPA), have been synthesized to use for electrochromic purpose $[19,20]$.

\section{EXPERIMENTAL}

2-Amino-6-methoxybenzothiazole (Merck, $98 \%$ ), 4fluorobenzonitrile (Acros, $98.7 \%$ ), cesium fluoride, (Acros, $98 \%$ ), dimethylsulfoxide (DMSO) (Merck, $98 \%$ ), $10 \%$ palladium on charcoal (Pd/C), (Fluka), ethanol (Merck, 99.7 $\%$ ), triphenylphosphite (Merck, $97 \%$ ), $\mathrm{CaCl}_{2}$ (Merck, $99 \%$ ), $\mathrm{N}$-methyl pyrrolidone (NMP) (Aldrich, $98 \%$ ), terephthalic

This is an open access journal, and articles are distributed under the terms of the Creative Commons Attribution-NonCommercial 4.0 International (CC BY-NC 4.0) License, which allows others to copy and redistribute the material in any medium or format, remix, transform, and build upon the material, as long as appropriate credit is given and the new creations are licensed under the identical terms. 
acid (Aldrich, $97 \%$ ), isophthalic acid (Aldrich, $97 \%$ ), 1,4dicarboxylic naphthalene acid (Aldrich, $94 \%$ ), biphenyl-4,4'dicarboxylic acid (Aldrich, $97 \%$ ), 4,4'-oxydibenzoic acid (Aldrich, $98 \%$ ).

Characterization technique: The spectrum of FT-IR for all compounds was performed by a Spotlight 400 Perkin-Elmer spectrometer. ${ }^{1} \mathrm{H}$ NMR $(400 \mathrm{MHz})$ and ${ }^{13} \mathrm{C}$ NMR $(100 \mathrm{MHz})$ data are recorded by a JEOL spectrometer. UV-visible absorption and photoluminescence spectrum were performed in $\left(10^{-5} \mathrm{M}\right)$ $\mathrm{N}$-methyl pyrrolidone on a Cary $60 \mathrm{UV}$-visible spectrophotometer.

The measurementos of X-ray were recorded by $\mathrm{CuK}_{\alpha}$ radiation beam (1 1 1/4 1.541_A) with Max Flax (CMF) mirror. Thermal and decomposition measurements were performed on a Perkin Elmer DSC6 instrument under $\mathrm{N}_{2}$ atmosphere with a scan rate of $20^{\circ} \mathrm{C} / \mathrm{min}$ and an SDT Q600 thermogravimetric analyzer.

\section{Synthesis of diphenylamine-diamine monomer (M)}

Synthesis of 4,4-dinitro-6-methoxybenzothiozolediphenylamine (I): In a round bottom flask $250 \mathrm{~mL}$ with a magnetic bar, $5.4 \mathrm{~g}(0.03 \mathrm{~mol})$ (2-amino, 6-methoxybenzothiazol) (a), $8.46 \mathrm{~g}(0.06 \mathrm{~mol}) p$-fluoronitrobenzene and 9.20 $\mathrm{g}(0.06 \mathrm{~mol})$ of $\mathrm{CsF}$ in $80 \mathrm{~mL}$ (DMSO) were refluxed to $120^{\circ} \mathrm{C}$ for $20 \mathrm{~h}$. The final solution was stream into $200 \mathrm{~mL}$ solution $\mathrm{CH}_{3} \mathrm{OH}-\mathrm{H}_{2} \mathrm{O}$ (1:1) to get precipitate after filtration washed with methanol and water several times and recrystallized from (DMF)/methanol to give dark yellow solid crystals $10.38 \mathrm{~g}$ (yield $82 \%$ ) of dinitro compound (I) m.p. $292-294{ }^{\circ} \mathrm{C}$. Anal. calcd. for $\mathrm{C}_{20} \mathrm{H}_{14} \mathrm{~N}_{4} \mathrm{O}_{5} \mathrm{~S}$ (422.42): C, 56.87; H, 3.34; N, 13.26; O, 18.94; S, 7.59. Found: C, $56.62 \%$; H, $2.96 \%$; N $13.46 \%$; O, $18.77 \%$. FT-IR: 1576, $1344\left(-\mathrm{NO}_{2}\right), 1234,1194,1139$, 1060 (benzothiazole). ${ }^{1} \mathrm{H}$ NMR ( $\left.400 \mathrm{MHz}, \mathrm{DMSO}-d_{6}, \delta, \mathrm{ppm}\right)$ : 8.05-7.98 (d, 4H, Ha), 7.58-7.47(d, 2H, Hc), 7.47-7.38 (d, $\left.4 \mathrm{H}, \mathrm{H}_{\mathrm{b}}\right), 7.05-6.97\left(\mathrm{~d}, 1 \mathrm{H}, \mathrm{H}_{\mathrm{d}}\right), 3.83\left(\mathrm{~s}, 3 \mathrm{H}, \mathrm{H}_{\mathrm{OCH}}\right) .{ }^{13} \mathrm{C} \mathrm{NMR}$ $\left(100 \mathrm{MHz}, \mathrm{DMSO}-d_{6}, \delta, \mathrm{ppm}\right): 174.55\left(\mathrm{C}_{4}\right), 156.76\left(\mathrm{C}_{9}\right)$, $148.62\left(\mathrm{C}_{3}\right), 145.52\left(\mathrm{C}_{6}\right), 137.43\left(\mathrm{C}_{10}\right), 131.92\left(\mathrm{C}_{5}\right), 124.84$ $\left(\mathrm{C}_{1}\right), 122.93\left(\mathrm{C}_{2}\right), 118.21\left(\mathrm{C}_{8}\right), 114.64\left(\mathrm{C}_{11}\right), 104.92\left(\mathrm{C}_{7}\right), 55.81$ $\left(\mathrm{C}_{\mathrm{CH} 3}\right)$.

Synthesis of 4,4-diamino-6-methoxybenzothiozolediphenylamine monomer $(\mathbf{M})$ : In a $250 \mathrm{~mL}$ stirred round flask, $10 \mathrm{~g}(0.024 \mathrm{~mol})$ dinitro intermediate, $0.20 \mathrm{~g} 10 \mathrm{wt} \% \mathrm{Pd} / \mathrm{C}$, $10 \mathrm{~mL} \mathrm{NH} 2-\mathrm{NH}_{2}$ hydrate in $120 \mathrm{~mL}$ Et-OH are refluxed at 130 ${ }^{\circ} \mathrm{C}$ for $12 \mathrm{~h}$. Then the $\mathrm{Pd} / \mathrm{C}$ powder was separated by filtration of the hot crude and cooled to form a pale white precipitate crystal after filtration and dried in vacuo at $80^{\circ} \mathrm{C}$ to give 8.15 $\mathrm{g}$ (yield $75 \%$ ) of diamine (M) as pale white crystals SchemeI. mp: $262-264{ }^{\circ} \mathrm{C}$. FT-IR: $3326,3272 \mathrm{~cm}^{-1}$ (-NH 2 stretch.). Anal. calcd. for $\mathrm{C}_{20} \mathrm{H}_{18} \mathrm{~N}_{4} \mathrm{OS}$ (362.45): C, 66.28; H, 5.01; N, 15.46; O, 4.41; S, 8.85 Found: C, $66.56 \%$; H, $5.21 \%$; N, $15.63 \%$. ${ }^{1} \mathrm{H}$ NMR (400 MHz, DMSO- $d_{6}, \delta$, ppm): 7.58-7.50 $(\mathrm{d}, 2 \mathrm{H}, \mathrm{Hc}), 7.11-7.06(\mathrm{~d}, 4 \mathrm{H}, \mathrm{Ha}), 7.02-6.96\left(\mathrm{~d}, 1 \mathrm{H}, \mathrm{H}_{\mathrm{d}}\right), 6.12-$ $6.05\left(\mathrm{~d}, 4 \mathrm{H}, \mathrm{H}_{\mathrm{b}}\right), 4.53$ (s, 2H, $\left.\mathrm{H}_{\mathrm{NH} 2}\right), 3.82\left(\mathrm{~s}, 3 \mathrm{H}, \mathrm{H}_{\mathrm{OCH}}\right) .{ }^{13} \mathrm{C}$ NMR (100 MHz, DMSO- $d_{6}, \delta$, ppm): $174.53\left(\mathrm{C}_{4}\right), 156.72\left(\mathrm{C}_{9}\right)$, $145.54\left(\mathrm{C}_{6}\right), 137.91\left(\mathrm{C}_{10}\right), 132.51\left(\mathrm{C}_{3}\right), 131.91\left(\mathrm{C}_{5}\right), 131.22$ $\left(\mathrm{C}_{2}\right), 118.20\left(\mathrm{C}_{8}\right), 117.22\left(\mathrm{C}_{1}\right), 114.62\left(\mathrm{C}_{11}\right) .104 .91\left(\mathrm{C}_{7}\right)$.

\section{Synthesis of polyamides (P1-P5)}

Synthesis of polyamide(P1): Synthesized polyamide (P1) was the example to explain the main synthetic path which used to prepare all the polymers. In a $50 \mathrm{~mL}$ stirred round-bottom flask, $1.10 \mathrm{~g}(0.002 \mathrm{~mol})$ diamine monomer $(\mathbf{M}), 0.50 \mathrm{~g}(0.002$ mol) of terephthalic acid R1, $3.0 \mathrm{~mL}$ triphenylphosphite (TPP), $4.0 \mathrm{~mL}$ NMP, $1.0 \mathrm{~mL}$ pyridine and $0.30 \mathrm{~g} \mathrm{CaCl}_{2}$. The flask was refluxed at $120{ }^{\circ} \mathrm{C}$ for $3 \mathrm{~h}$. The solution of polyamide product was poured into $200 \mathrm{~mL}$ of $\mathrm{CH}_{3} \mathrm{OH}$ with stirring gave a fibrous, dark brown precipitate after filtration and washed completely by methanol and hot water and dried [21], (1.15 g (78 \% yield) m.p. 331-334 Scheme-II. FT-IR (film): 3320 (amide $\mathrm{N}-\mathrm{H}$ stretch), $1664 \mathrm{~cm}^{-1}$ (amide $\mathrm{C}=\mathrm{O}$ stretch). All polyamides were synthesized by same method.

Synthesis of polyamide (P2): This polyamide was synthesized by the same route as explained in method of P1. Pale brown (72\% yield), m.p. $321-323^{\circ} \mathrm{C}$. FT-IR (film): $3332(\mathrm{~N}-\mathrm{H}$ stretch for amide part), $1667 \mathrm{~cm}^{-1}$ (amide $\mathrm{C}=\mathrm{O}$ stretch group).

Synthesis of polyamide (P3): This polyamide was synthesized by the same route as explained in method of P1. Pale brown, (81\% yield), m.p. $332-334^{\circ} \mathrm{C}$. FT-IR (film): $3336(\mathrm{~N}-\mathrm{H}$ stretch for amide part), $1662 \mathrm{~cm}^{-1}$ (amide $\mathrm{C}=\mathrm{O}$ stretch).

Synthesis of polyamide (P4): This polyamide was synthesized by the same route as explained in method of P1. Black brown, (68\% yield), m.p. $322-324^{\circ} \mathrm{C}$. FT-IR (film): 3330 (N$\mathrm{H}$ stretch for amide part), $1665 \mathrm{~cm}^{-1}$ (amide $\mathrm{C}=\mathrm{O}$ stretch).

Synthesis of polyamide (P5): This polyamide was synthesized by the same route as explained in method of P1. Dark yellow, (75\% yield), m.p. $325-327{ }^{\circ} \mathrm{C}$. FT-IR (film): 3338 ( $\mathrm{N}-\mathrm{H}$ stretch for amide part), $1661 \mathrm{~cm}^{-1}$ (amide $\mathrm{C}=\mathrm{O}$ stretch).

\section{RESULTS AND DISCUSSION}

Monomer synthesis: Intermediate diphenylamine monomer 4,4-diamino-6-methoxybenzothiozolediphenylamine (M) was synthesized via double $\mathrm{N}$-arylation nucleo-

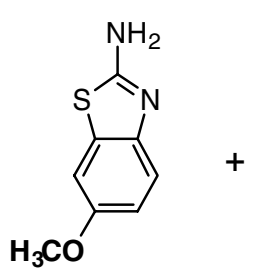

(a)<smiles>O=[N+]([O-])c1ccc(F)cc1</smiles>

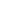

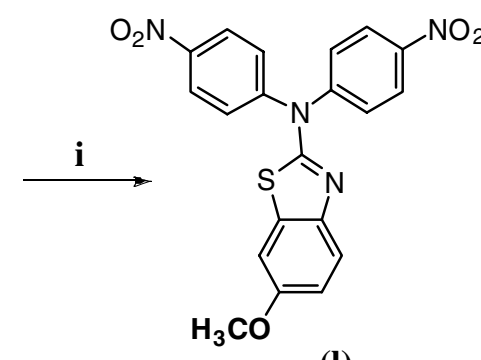

(l)<smiles>COc1ccc2nc(N(c3ccc(N)cc3)c3ccc(N)cc3)sc2c1</smiles>

(M)

Reaction Conditions: (i) $\mathrm{CsF}$

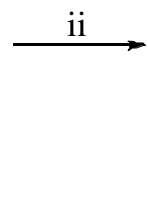

(ii) $10 \% \mathrm{Pd} / \mathrm{C}, . \mathrm{NH}_{2}-\mathrm{NH}_{2} \cdot \mathrm{H}_{2} \mathrm{O}$, EtOH

Scheme-I: Synthetic path for the monomer (M) 


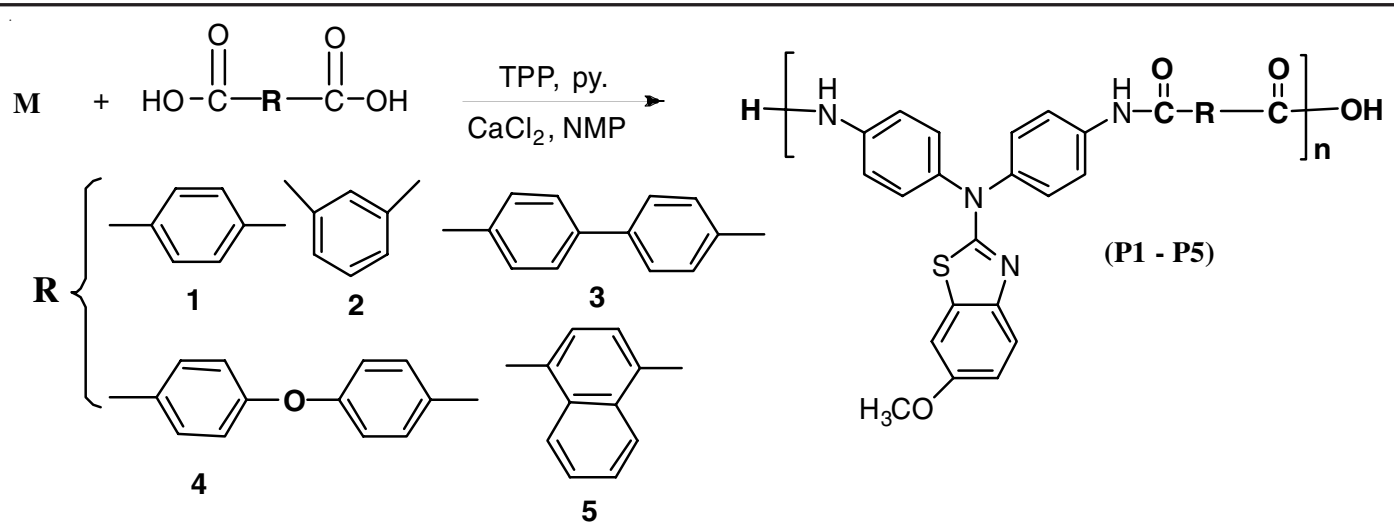

Scheme-II: Synthetic route for polyamides (P1-P5)

philic aromatic fluoro-displacement reaction of two equivalent 4-fluoronitrobenzene with compound (a), then by catalytic reduction using $\mathrm{Pd} / \mathrm{C}$ and $\mathrm{NH}_{2}-\mathrm{NH}_{2}$ in $\mathrm{EtOH}$ of the intermediate dinitro compound (I).The structure of (I) and (M) was characterized by elemental analysis, FT-IR, ${ }^{1} \mathrm{H}$ and ${ }^{13} \mathrm{C}$ NMR spectroscopic techniques. The $\mathrm{NO}_{2}$ part of (I) showed two characteristic bands 1576 and $1344 \mathrm{~cm}^{-1}$ which pass away after reduction. The monomer with di- $\mathrm{NH}_{2}(\mathbf{M})$ gave characteristic$\mathrm{NH}_{2}$ absorptions in the regions of $3326,3272 \mathrm{~cm}^{-1}$ (Fig. 1).
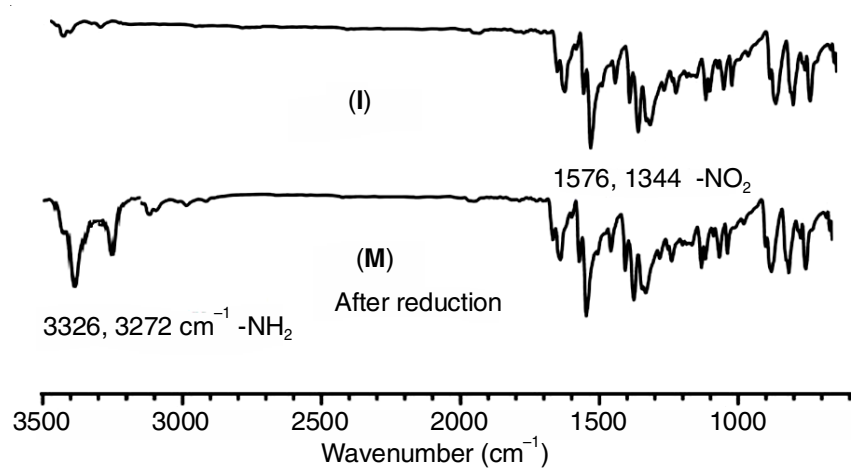

Fig. 1. FTIR spectra of (I), (M)

The ${ }^{1} \mathrm{H}$ and ${ }^{13} \mathrm{C}$ NMR spectrum of compounds (I), (M) are expressed in the Figs. 2 and 3, respectively. The spectra in the figures agreed well with the suggested unit structures. The complete reduction of nitro groups of the intermedaite compounds to the amino groups monomers are confirmed by the strong field shift of aromatic hydrogens and by the resonance indicators $3.82 \mathrm{ppm}$ assignable to the amino hydrogens.

Poly(amine-amide) synthesis: Scheme-II shows that polyamides (P1-P5) were synthesized by poly-condensation reactions from the diamines monomer (M) by differnet aromatic di-carboxylic acids by the Yamazaki reaction conditions. The yield products showed highly viscous solutions with high inherent viscosities in the range 0.62-0.87 dL/g (Table-1).

FTIR spectra of these polyamides were in the range 3338$3320 \mathrm{~cm}^{-1}$ (N-H stretch amide group) and 1664-1661 $\mathrm{cm}^{-1}$ ( $\mathrm{C}=\mathrm{O}$ stretch for amide for group) (Fig. 4).

\section{Polyamides properties}

Solubility and inherent viscosity: The resultant polyamides in $10 \%$ (w/v) different solvents exhibited excellent solubility because of the presence of diphenylamine unit (DPA)

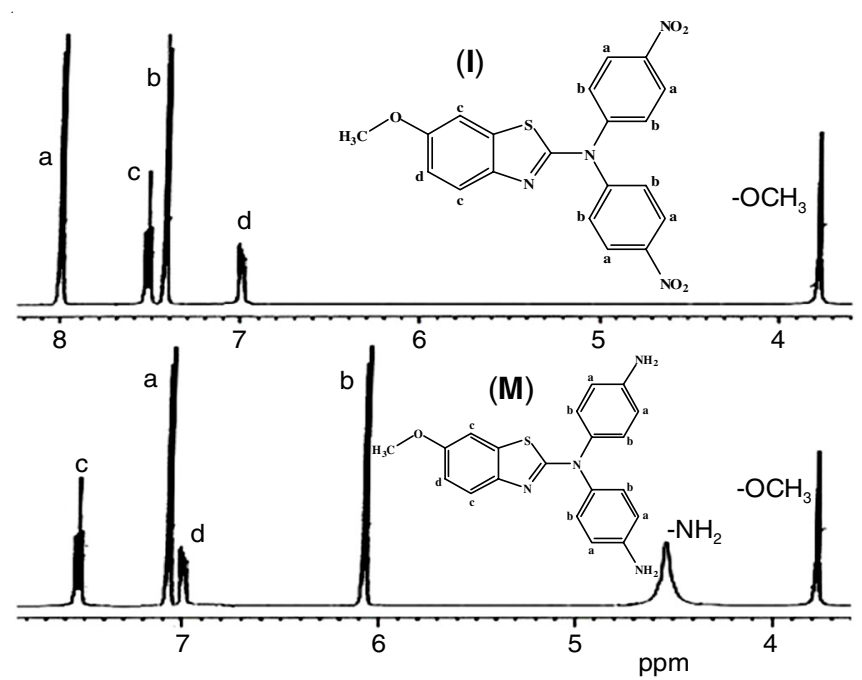

Fig. 2. ${ }^{1} \mathrm{H}$ NMR spectra of (I) and (M)
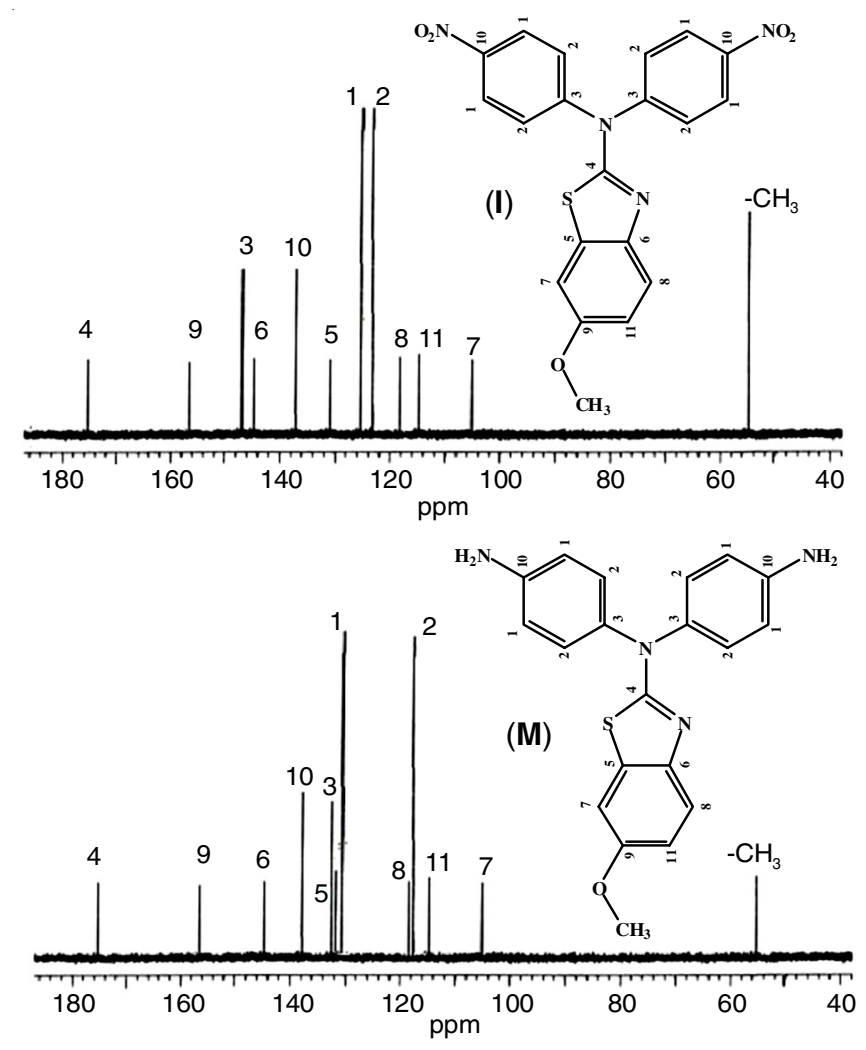

Fig. $3 .{ }^{13} \mathrm{C}$ NMR spectra of (I) and (M) 
TABLE-1

INHERENT VISCOSITY $\left(\eta_{\text {inh }}\right)$ AND SOLUBILITY BEHAVIOUR OF SYNTHESIZED POLYAMIDES

\begin{tabular}{cccccccc}
\hline \multirow{2}{*}{$\begin{array}{c}\text { Polyamide } \\
\text { codes }\end{array}$} & $\eta_{\text {inh }}{ }^{a}(\mathrm{dL} / \mathrm{g})$ & \multicolumn{5}{c}{ Solubility in the solvents } \\
\cline { 3 - 7 }${ }^{\mathrm{b}}$ & DMSO & DMF & NMP & DMAc & $m$-Cresol & THF \\
\hline P1 & 0.62 & ++ & ++ & ++ & ++ & - & - \\
P2 & 0.65 & ++ & ++ & ++ & ++ & + & + \\
P3 & 0.76 & ++ & ++ & ++ & ++ & + & + \\
P4 & 0.84 & ++ & ++ & ++ & ++ & + \\
P5 & 0.87 & ++ & ++ & ++ & ++ & + & + \\
\hline
\end{tabular}

${ }^{\mathrm{a}}$ Measured at a concentration of $10^{-5} \mathrm{M}$ in DMSO; ${ }^{\mathrm{b}}$ Solubility was tested with $10 \%(\mathrm{w} / \mathrm{v})$ of stirred solvent; ++: High solubility at room temperature; +: Low solubility at room temperature; -: Non solubility

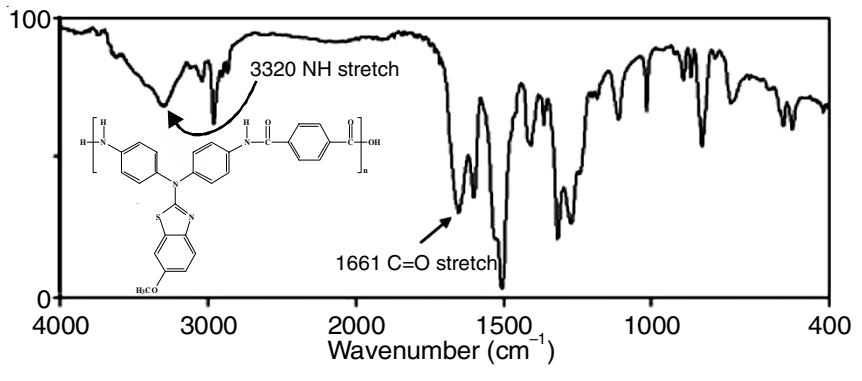

Fig. 4. FTIR spectra of $\mathbf{P 1}$

so polyamides P3, P4, P5 have more solubility than others because of bigger at pending phenyl unit chromophores in the recurrent unity, which lead to increase the open bulky in the polyamide chains to let the insertion of additional solvent in. The inherent viscosity of synthesized polyamides was measured at a concentration of $\left(10^{-5} \mathrm{M}\right)$ in DMSO solvent. The polyamides solubility and inherent viscosity was summarized in Table-1.

$\mathrm{X}$-ray diffraction data: The diffraction patterns appear in Fig. 5 explain that the polyamides X-ray diffraction measurements exhibited that all the polyamides were ultimately amorphous.

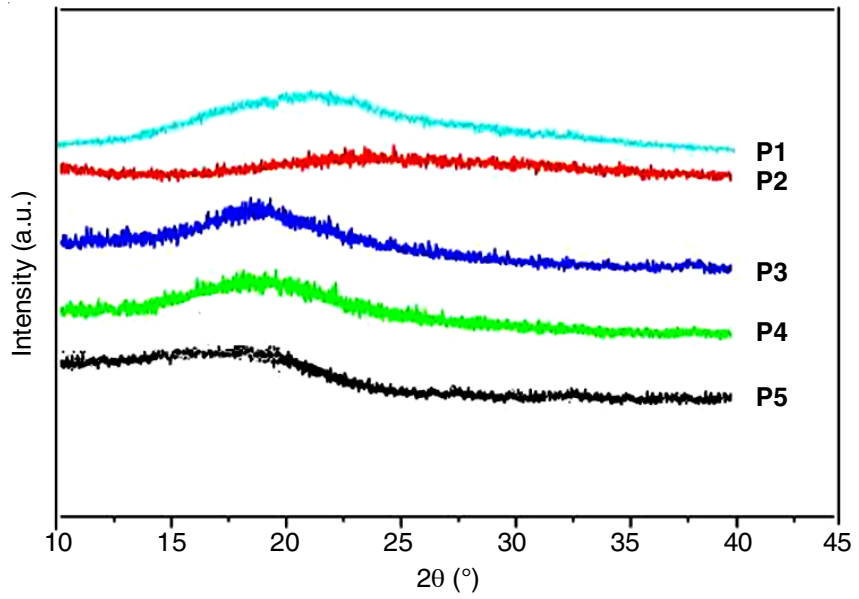

Fig. 5. WAXD patterns of polyamides (P1-P5)

Thermal properties: DSC and TGA technique was applied to evaluate the thermal behaviour of the synthesized polymers and the results are outline in Table-2. These polyamides recorded glass transition $\mathrm{T}_{\mathrm{g}}$ values between (322-306) ${ }^{\circ} \mathrm{C}$ in the scan rate at $20^{\circ} \mathrm{C} / \mathrm{min}$ in $\mathrm{N}_{2}$ atmosphere. The highest $\mathrm{T}_{\mathrm{g}}$ value were of polyamides $\mathbf{P 1}$ and $\mathbf{P 3}$ because of the rigidity and low turning of its diacid groups, in other side the lower $T_{\mathrm{g}}$ values of polyamides $\mathbf{P 2}, \mathbf{P 4}$ and $\mathbf{P 5}$ can be illustrated in high elasticity and high turning of its diacid groups [22] (Fig. 6).

\begin{tabular}{ccccc}
\multicolumn{5}{c}{ TABLE-2 } \\
THERMAL PROPERTIES OF POLYAMIDES \\
\hline $\begin{array}{c}\text { Polymer } \\
\text { code }\end{array}$ & $\mathrm{T}_{\mathrm{a}}{ }^{\mathrm{a}}\left({ }^{\circ} \mathrm{C}\right)$ in & $\begin{array}{c}10 \% \mathrm{Td}^{\mathrm{b}} \\
\left({ }^{\circ} \mathrm{C}\right) \text { in air }\end{array}$ & $\begin{array}{c}\text { Char }(\text { wt. } \\
\%)\end{array}$ & Yield $^{\mathrm{c}}(\%)$ \\
\hline P1 & $\mathrm{N}_{2}$ & 600 & 561 & 63 \\
P2 & 322 & 550 & 510 & 55 \\
P3 & 306 & 590 & 560 & 60 \\
P4 & 306 & 550 & 510 & 55 \\
P5 & 307 & 352 & 549 & 59 \\
\hline
\end{tabular}

${ }^{\mathrm{a} o} \mathrm{C}$ Midpoint of baseline DSC trace in nitrogen; ${ }^{\text {bo }} \mathrm{C}$ Decomposition at which a $10^{\mathrm{d}}$ wt $\%$ at a rate of $20^{\circ} \mathrm{C} / \mathrm{min}$; ${ }^{\circ}$ Char yield percent at $800{ }^{\circ} \mathrm{C}$ in $\mathrm{N}_{2}$.

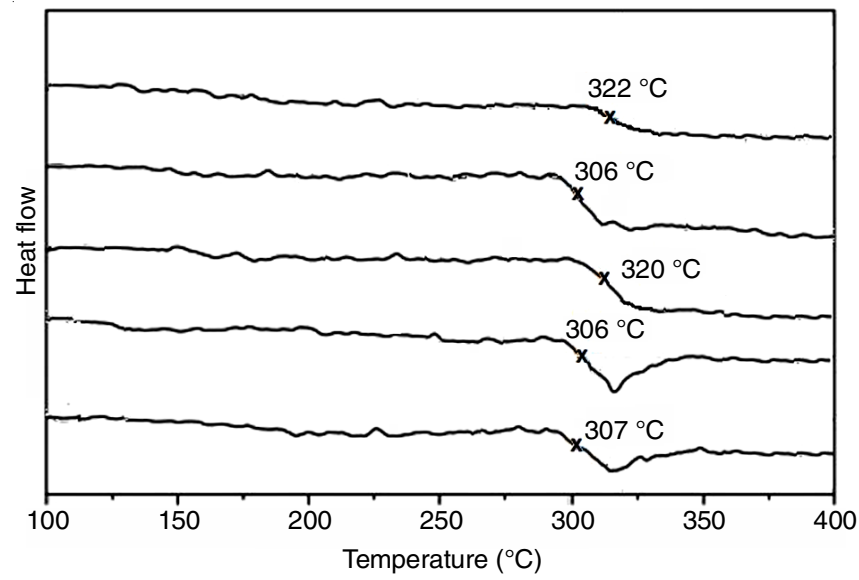

Fig. 6. DSC of polyamides (P1- P5) in $\mathrm{N}_{2}$ atmosphere

Synthesized polyamides exhibited excellent thermal stability. They have onset decomposition after about $450{ }^{\circ} \mathrm{C}$. The polyamides $10 \% \mathrm{~T}_{\mathrm{g}}$ were in the range of $550-600{ }^{\circ} \mathrm{C}$ in nitrogen and $510-561{ }^{\circ} \mathrm{C}$ in the air with char yield at $800^{\circ} \mathrm{C}$ in $\mathrm{N}_{2}$ of 55-63 wt \% and 53-57 wt \% in air. The high amount of the polymers char can be illustrated that they have high aromatic rings (Fig. 7).

Electrochemical and optical behaviours: The electrochemical and optical behaviours of all the synthesized polyamides were studied by UV-visible, photoluminescence spectroscopy (PL) and cyclic voltammetry (CV) (Table-3). Polyamides (P1-P5) in DMSO solution gave strong UV-visible absorption bands at the range $332-356 \mathrm{~nm}$. The absorption bands are resulting from the $\pi-\pi^{*}$ transition between the nitrogen atoms and aromatic rings. The solutons of theses polyamides in DMSO gave photoluminescence emission spectra maxima at the range $422-467 \mathrm{~nm}$ in the blue region. Fig. 8 shows the UV-visible absorption and photoluminescence spectra of polyamides (P1-P5). The (P5) PL spectra showed a slightly shorter emission wavelength $\lambda$ PL than others due to 

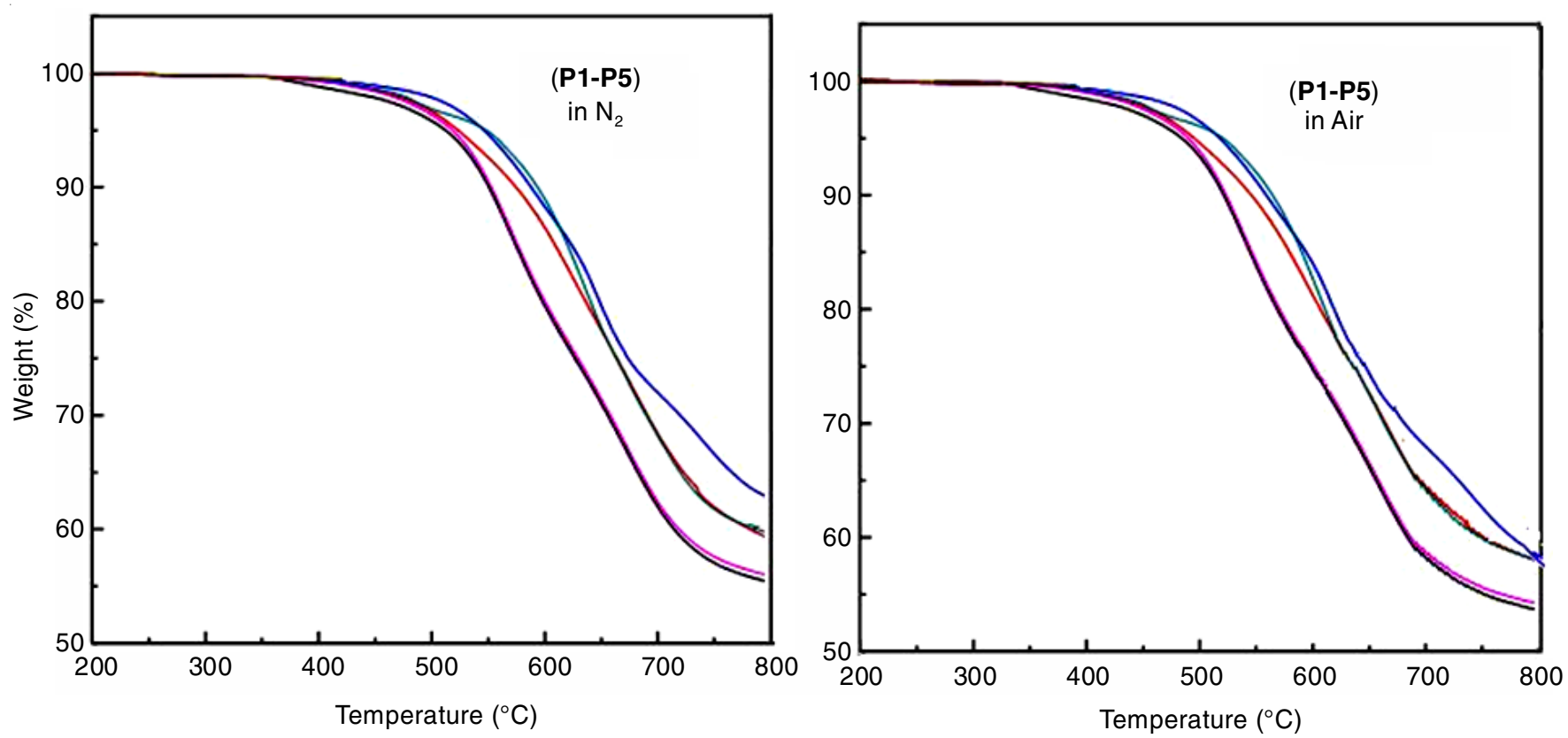

Fig. 7. TGA of polyamides (P1-P5) in $\mathrm{N}_{2}$ and air atmosphere

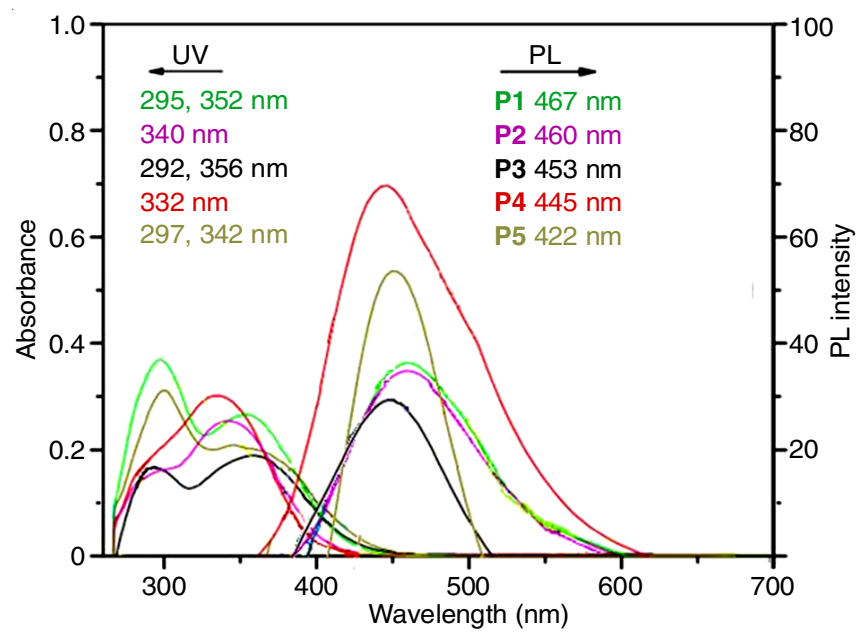

Fig. 8. UV-visible and (PL) spectroscopy of (P1-P5)

the disturbed chain-chain packing caused by the incorporate the bulky 1,4-naphthalene group in the repeat unit.

The red-ox action of polyamides (P1-P5) was studied by cyclic voltammetry for the molding sheet over ITO-plated glass base as a working electrode in $\mathrm{CH}_{3} \mathrm{CN}$ with $0.1 \mathrm{M}$ of TBAP as an electrolyte, under nitrogen atmosphere.

Each of these polyamides showed one reversible redox wave (Fig. 9). Cyclic voltammograms of polyamides (P1-P5)

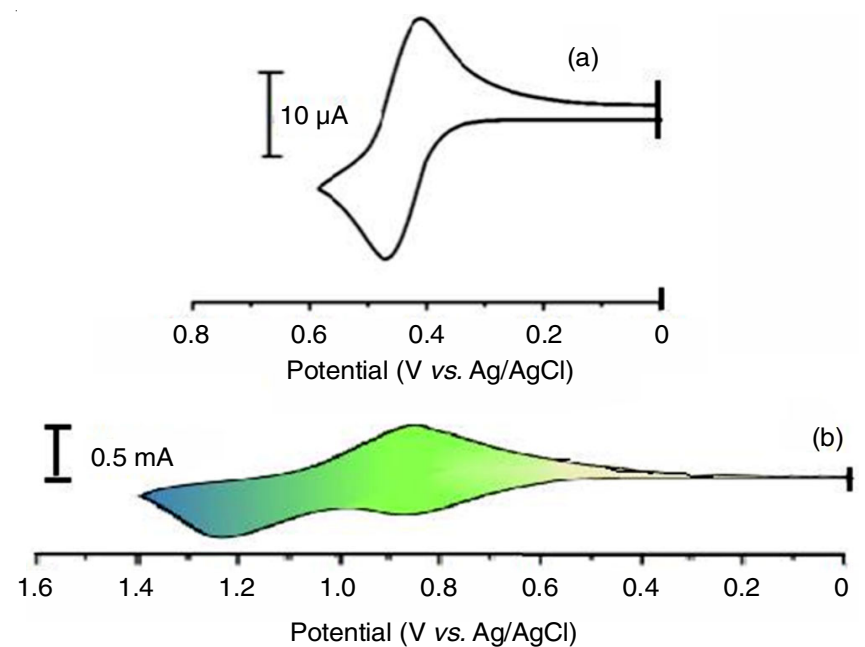

Fig. 9. Cyclic voltammogram of (a) $\left(\mathrm{Fc} / \mathrm{Fc}^{+}\right)$, (b) (P1) sheet onto an ITOplated glass substrate in $\mathrm{CH}_{3} \mathrm{CNe}$ with $0.1 \mathrm{M}$ TBAP at scan rate of $0.2 \mathrm{~V} / \mathrm{s}$

performed at scan rate of $0.2 \mathrm{~V} / \mathrm{s}$. The polyamides recorded one reversible oxidation wave versus $\mathrm{Ag} / \mathrm{AgCl}$. The polyamides exhibited good reversible electrochromic properties by continuous 7 scans $0.0-1.40 \mathrm{~V}$ leading to change the original pale yellowish colour to blue. The HOMO and LUMO energy levels of all polyamides are calculated from the onset absorp-

TABLE-3

OPTICAL AND ELECTROCHEMICAL PROPERTIES FOR THE POLYAMIDES

\begin{tabular}{|c|c|c|c|c|c|c|c|}
\hline $\begin{array}{l}\text { Polyamide } \\
\text { code }\end{array}$ & $\lambda_{\mathrm{abs}, \max }(\mathrm{nm})^{\mathrm{a}}$ & $\lambda_{\text {abs, Onset }}(\mathrm{nm})^{\mathrm{b}}$ & $\lambda_{\mathrm{PL}}(\mathrm{nm})^{\mathrm{c}}$ & $\begin{array}{l}\text { Oxidation (V) (vs. } \\
\mathrm{Ag} / \mathrm{AgCl})(\mathrm{gap})^{\mathrm{d}}\end{array}$ & $\begin{array}{c}(\mathrm{HOMO}- \\
\text { LUMO) }(\mathrm{eV})\end{array}$ & $\mathrm{HOMO}^{\mathrm{e}}(\mathrm{eV})$ & $\operatorname{LUMO}^{\mathrm{f}}(\mathrm{eV})$ \\
\hline P1 & 295,352 & 425 & 467 & 1.05 & 2.92 & 5.45 & 2.53 \\
\hline $\mathbf{P 2}$ & 340 & 422 & 460 & 1.06 & 2.94 & 5.46 & 2.52 \\
\hline P3 & 292,356 & 462 & 453 & 1.08 & 2.68 & 5.48 & 2.80 \\
\hline P4 & 332 & 423 & 445 & 1.07 & 2.93 & 5.47 & 2.54 \\
\hline P5 & 297,342 & 460 & 422 & 1.04 & 2.61 & 5.45 & 2.83 \\
\hline
\end{tabular}

${ }^{\mathrm{a}} \mathrm{UV}$-visible absorption in $\left(10^{-5} \mathrm{M}\right)$ DMSO; ${ }^{\mathrm{b}} \mathrm{UV}$-visible absorption in (NMP $\left.1 \mathrm{mg} / \mathrm{mL}\right)$; ${ }^{\mathrm{C} L}$ spectra in $\left(10^{-5} \mathrm{M}\right) \mathrm{DMSO}$; ${ }^{\mathrm{d}}$ gap = $1240 / \lambda$ onset of polymer films; ${ }^{\mathrm{e}} \mathrm{The} \mathrm{HOMO}$ energy levels respect to $\left(\mathrm{Fc} / \mathrm{Fc}^{+}\right)(4.8 \mathrm{eV}) ;{ }^{\mathrm{f}} \mathrm{LUMO}$ energy levels. 
tion of the UV-visible absorption of thin films and oxidation half-wave potentials and [23]. The standard external redox of $(\mathrm{Fc} / \mathrm{Fc}+) \mathrm{E} 1 / 2$ is $0.41 \mathrm{~V} v s . \mathrm{Ag} / \mathrm{AgCl}$ and its HOMO energy is $4.80 \mathrm{eV}$ with consideration to the zero vacuum scale.

\section{Conclusion}

In this work, it has been successfully prepared a new (benzothiazole) diphenylamine-containing diamine monomer (M). New aromatic amorphous polyamides with excellent thermal properties were synthesized via the phosphorylation polycondensation technique from the reaction of several aromatic dicarboxylic acids with this monomer. These polyamides showed perfect electrochromic properties stability with the electrochemical to change the colour from yellow to green and then blue so all the synthesized polyamides may be available for applications in electroluminescent devices as holetransporting sheet and electrochromic materials due to their proper HOMO values.

\section{CONFLICT OF INTEREST}

The author declares that there is no conflict of interests regarding the publication of this article.

\section{REFERENCES}

1. J.A. Reglero-Ruiz, M. Trigo-López, F.C. Garcia and J.M. Garcia, Polymers, 9, 414 (2017);

https://doi.org/10.3390/polym9090414.

2. E. HaLasa and M. Heneczkowski, Polimery (Warsaw), 43, 1 (1998).

3. M.Z. Elsabee, R.E. Morsi and S. Selim, 30, 387 (2018); https://doi.org/10.1177/0954008317699259.

4. S.-H. Hsiao and Y.-H. Chang, Eur. Polym. J., 40, 1749 (2004); https://doi.org/10.1016/j.eurpolymj.2004.04.019.

5. S.H. Hsiao and S.L. Cheng, J. Polym. Sci. A Polym. Chem., 53, 496 (2015); https://doi.org/10.1002/pola.27465.

6. M. Ghaemy and S.M. Amini Nasab, React. Funct. Polym., 70, 306 (2010); https://doi.org/10.1016/j.reactfunctpolym.2010.02.004.

7. R. Friend, R.W. Gymer, A.B. Holmes, J.H. Burroughes, R.N. Marks, C. Taliani, D.D.C. Bradley, D.A.D. Santos, J.L. Brédas, M. Lögdlund and W.R. Salaneck, Nature, 397, 121 (1999); https://doi.org/10.1038/16393.
8. Y.-H. Chou, H.-J. Yen, C.-L. Tsai, W.-Y. Lee, G.-S. Liou and W.-C. Chen, J. Mater. Chem. C Mater. Opt. Electron. Devices, 1, 3235 (2013); https://doi.org/10.1039/c3tc30252k.

9. K.Y. Law, Chem. Rev., 93, 449 (1993); https://doi.org/10.1021/cr00017a020.

10. U. Mitschke and P. Bäuerle, J. Mater. Chem., 10, 1471 (2000); https://doi.org/10.1039/a908713c.

11. S.R. Forrest, Chem. Rev., 97, 1793 (1997); https://doi.org/10.1021/cr9410140.

12. T. Zhang, S. Liu, D.G. Kurth and C.F.J. Faul, Adv. Funct. Mater, 19, 642 (2009); https://doi.org/10.1002/adfm.200801409.

13. P.M. Beaujuge and J.R. Reynolds, Chem. Rev., 110, 268 (2010); https://doi.org/10.1021/cr900129a.

14. M. Liang and J. Chen, Chem. Soc. Rev., 42, 3453 (2013); https://doi.org/10.1039/c3cs35372a.

15. W.P. Lin, S.-J. Liu, T. Gong, Q. Zhao and W. Huang, Adv. Mater, 26, 570 (2014); https://doi.org/10.1002/adma.201302637.

16. J.H. Wu and G.S. Liou, Adv. Funct. Mater, 24, 6422 (2014); https://doi.org/10.1002/adfm.201401608.

17. S.-H. Cheng, S.-H. Hsiao, T.-H. Su and G.-S. Liou, Macromolecules, 38, 307 (2005); https://doi.org/10.1021/ma048774d.

18. H.-J. Yen and G.-S. Liou, Polym. Chem., 3, 255 (2012); https://doi.org/10.1039/C1PY00346A.

19. H.M. Wang and S.H. Hsiao, J. Polym. Sci. A Polym. Chem., 52, 272 (2014); https://doi.org/10.1002/pola.27001.

20. Y. Wang, Y. Liang, J. Zhu, X. Bai, X. Jiang, Q. Zhang and H. Niu, RSC Adv., 5, 11071 (2015); https://doi.org/10.1039/C4RA12970A.

21. N. Yamazaki, M. Matsumoto and F. Higashi, J. Polym. Sci.: Polym. Chem., 13, 1373 (1975); https://doi.org/10.1002/pol.1975.170130609.

22. T.H. Su, S.H. Hsiao and G.S. Liou, J. Polym. Sci. A Polym. Chem., 43, 2085 (2005); https://doi.org/10.1002/pola.20666.

23. D. De Leeuw, M.M.J. Simenon, A.R. Brown and R.E.F. Einerhand, Synth. Mater, 87, 53 (1997); https://doi.org/10.1016/S0379-6779(97)80097-5. 